\title{
College English Test: To Be Abolished or To Be Polished
}

\author{
Fei Ma \\ College English Department, Zhejiang Wanli University, Ningbo, China; \\ The University of Nottingham Ningbo China
}

\begin{abstract}
College English Test (CET) is a national standardized achievement test in mainland China. As a test with government backing, its passing rate has been used as one important index to evaluate higher institutions' teaching quality, which has pushed institutions to improve the teaching facilities and enhance quality of teaching staff for College English. It is believed that this has ever promoted the rapid growth of undergraduates' English level and accumulated knowledge for test development. Meanwhile Chinese society has imposed upon CET extra value, which makes it a high-stakes test and its negative impacts are emerging. It has resulted in test-oriented education and become a hurdle to College English reform. In addition its validity and fairness are constantly being challenged. After carefully balancing its positive and negative backwash to College English teaching and learning, I propose that a substantial reform of the present CET might be a feasible solution. Government's withdraw of its administrative role from CET and a change from achievement to proficiency test should be the orientation of reform. Furthermore, the validity of the test needs to be further improved.
\end{abstract}

Index Terms - College English, College English Test, language testing

\section{INTRODUCTION}

College English Test (CET) is a national standardized achievement test in mainland China. It is led by Higher Educational Department, Ministry of Education, developed by National College English Testing Committee (NCETC), jointly implemented with the help of the National Education Examinations Authority (NEEA) (NCETC, 2006). CET4 and CET6 are held twice each year respectively in June and December. The test takers are non-English major students in higher education institutions. The CET Spoken English Test (CET-SET) was initiated in 1999, which is only accessible to students whose CET4 score is 550 or above, or whose CET6 score is 520 or above.

After CET's inception in 1987, its passing rate has been used as one important index to assess the teaching quality of higher education institutions. CET has been exerting a big influence upon English language education in Chinese universities. Almost every university wants to do better in the passing rate since it means better reputation, more motivated students and more government financial support. As a result, the course of College English soon achieved its important position in the higher education system. As a government backed test, CET has quickly got recognition by the society. The employers regard CET certificate as one important quality of college graduates. College students are stimulated to spend time and effort on English learning. These factors objectively contribute to the improvement of teaching and learning of College English.

However, CET is a double blade sword. It has directly resulted in test-oriented education. Out of utilitarianism, both universities and students favor the short-term benefits and reluctant to concentrate on training of communicative competence. Quality education has become an empty talk. Besides, its validity and reliability are constantly challenged. Just like Liu and Dai's (2004) claimed, 'Its designers jungle the figures about its validity and reliability from the data of millions of takers only to mislead the less informed. Those who know about language testing and statistics have always taken their figures with a big grain of salt.' (p.6). The reservation or revocation of CET has been hotly debated for years. With is growing side effects, there is an urgent need to find a solution.

\section{REVIEW OF CONCEPTS}

In terms of language testing, two key criteria of evaluation in any measurement are:

- Whether we are measuring what we intend to measure;

- Whether the same measurement process yields the same results (Columbia Uni., 2014).

These two concepts are validity and reliability. Lado (1961) ever asked, 'Does a test measure it purports to measure? If it does, it is valid.'(p.132). Weir (2010) noted that validity is perhaps better defined as the extent to which a test can be shown to produce data, i.e., test scores, which are an accurate representation of a candidate's level of language knowledge or skills. It is validity that makes a test useful. A valid test must also be reliable. Reliability is often defined as consistency of measurement in a test, which means reliability can be considered a function of the consistency of scores from one set of tests and test tasks to another (Bachman \& Palmer, 1999). Namely, a test is regarded with reliability if it produces similar results under similar conditions. It is impossible to detour these two indexes if CET 
want to be useful and authoritative.

The effect of testing on teaching and learning is known as backwash (Hughes, 2003), which has an impact not only on teachers and learners, but on educational systems in general, and on society at large (Hughes, 2003). The backwash effect can be beneficial or negative. As far as CET is concerned, the positive backwash may diagnose the weakness and strength of College English teaching and learning, so as to improve it. On the other hand, the negative backwash may give out misleading information and be counteractive to teaching and learning. It is very likely that negative backwash will result in a lot of waste of time and effort. It is the responsibility and conscience of test designers and administrators to maximize the former and minimize the latter.

\section{THE RISE OF CET}

\section{A. The Social Context under Which CET Was Initiated}

Language test never takes place in isolation. It is done for a particular purpose and in a specific context (Bachman, 1999). CET is no exception. Domestically, after the Reform and Opening-up policy was implemented in 1977, China's communication with the world began to soar in a way of geometric growth. Attracted by the favorable investment policy, numerous foreign companies began to set up enterprises in mainland China, and many joint ventures were established as well. At the same time, China's foreign trade was growing steadily. As a result, a large number of talents who could communicate in English were urgently demanded by the society.

Internationally, the concepts of global village and economic globalization brought about the need for a lingua franca, which inevitably has fallen upon English. In human history English has never penetrated so widely and deeply into the hearts and minds of individuals and societies as it does today (Feng, 2011). Feng (2011) appropriated a metaphor the 'third wave' to describe the current surge of English spreading in the contemporary world. If China wants to accelerate its integration into the world, English as a tool has become prerequisite.

Both the domestic economic development and international communication demanded a large number of talents who know English. However, English education in 1980s couldn't meet the demands. The English education at that time was at an embarrassing low level, which was influenced both by international political climate and domestic turbulence. From the year 1949 when People's Republic of China was founded to the early 1960s, China had developed a very intimate relation with Soviet Union, so Russian had been the dominating foreign language in all levels of educational institutions. With the breakdown of Sino-Soviet relation, Russian lost its prestige and popularity and English became the favored foreign language (Gil \& Adamson, 2011). However it didn't last long before the Cultural Revolution which started in 1966 and ended in 1976 totally damaged the whole educational system. The intellectuals mainly teachers were indiscriminately labeled as 'chou lao jiu' (stinking number nine). Teachers were often publicly denounced and humiliated by students and the school education was in a paralyzed state. In addition, English language was regarded as the capitalist culture which was under condemnation. Therefore when the Reform and Opening-up policy was initiated in 1977, the central government found that English education in China seriously lagged behind the economic and cultural advance.

Under these circumstances, the central government realized actions must be taken to improve the situation. College English Teaching Syllabus (Science and Technology) was therefore implemented in 1985 and College English Teaching Syllabus (Arts and Science) in 1986 by State Education Commission (former Ministry of Education) (Jin, 2011), which played a significant role in College English education and set an teaching aim and requirement for college English. The Syllabuses have divided College English into 6 bands, among which bands 1-4 are compulsory and band 5-6 are elective. In the document to approve the Syllabus by State Education Commission (FLTRA, 1985), it formulated that standardized tests would be administered to students when they finish band 4/6. As a result, CET4 emerged in 1987 and CET6 in 1989, in an aim to check how well the two syllabuses are implemented and provide feedback for College English teaching.

\section{B. The Orientation of CET}

Purpose: The most prevalent use of language test is for purpose of evaluation in educational programs (Bachman, 1999), which is identical to Hughes's idea of measuring language proficiency (2003). In addition Hughes proposed two additional purposes: to discover how successful students have been in achieving the objective of a course of study, or to diagnose students' strengths and weaknesses to identify what they know and what they don't know (2003). The present CET is claimed to theoretically serve the above mentioned three purposes. CET is designed to check how well the Teaching Syllabus is implemented, assess students' all-around ability to use English, and exert a positive influence on the accomplishment of College English teaching aim (NCETC, 2006). It implies that CET4/6 may also help to diagnose students' area of strength and weakness. It is believed that its backwash will help College English reform and design more effective teaching models.

Achievement or proficiency test: Compared to Language proficiency test which is designed to measure test takers' ability to function in the target language regardless of the type of training they have had in that language, achievement test is used to measure skills and knowledge the test takers have learned in a given grade level, usually after a specific part of the curriculum has been covered (ILR, 2013). College English is a required course based on classroom instruction with very formal textbooks, and CET is designed to evaluate college students' language level when they 
finish learning the textbooks from band 1 to band 4. Besides, CET has its own testing syllabus, which gives a detailed introduction of its purpose, construct, score interpretation and score report, etc. It has the key factors of being an achievement test. On top of that, all the students are tested at the same time, under similar conditions, with almost the same items. Considering these factors, CET can be described as a standardized achievement test. However in practice, the society has imposed on it extra values. Employers regard CET certificate (now 425 points or above) as one of basic qualities of college graduates, and students also see the certificate or good score a stepping stone for a better career. In the eyes of employers and students, it is more like a proficiency test.

Content and interpretation: The content of language tests can be based on either a theory of language proficiency or a specific domain of content (Bachman, 1999). CET falls into the latter, which is based on College English Teaching Syllabus (before 2004) and College English Curriculum Requirements (after 2004). The Syllabus serves as the content criterion. Exactly, CET assesses students' abilities in writing, reading, listening, translating, as well as speaking which is tested in a different time and only accessible to a certain group of students. As for scoring, CET has its carefully designed marking criterion, especially for subjective items, such as writing and translation. After score equating and score normalization, the score being reported to students ranges from 220 to 710 , with a mean of 500 and standard deviation of 70. Generally, it is called a criterion-related norm-referenced test (NCETC, 2006). Criterion-related refers to that the test paper is constructed according to the criterion regulated by College English Curriculum Requirements, and norm-referenced means the norm ${ }^{1}$ of each part of testing paper is referenced when its raw score is transformed into reporting score.

\section{The Major Development Phases of CET}

Language testing has emerged in the wake of language teaching. Up to now language testing has experienced four periods of development: Pre-scientific Testing Period (before 1950s), Psychometric-Structuralist Period (1950s-1970s), Psycholinguistic-Sociolinguistic Period (1970s - 1980s) and Communicative Testing Period (1980s-) (Wang, 2011). The last three periods have exerted important impact upon CET development. The discrete-point test proposed by Psychometric-Structuralists originates from the idea that language elements and skills could be tested separately (Lado, 1961). It exercised a big influence upon CET construction in its early phase. The CET construct in early phase mainly consisted of Listening, Vocabulary \& Structure, Reading and Writing with multiple-choice as the dominant items. In psycholinguistic-Sociolinguistic period, global integrative approach began to win popularity, which advocated integrative test as opposed to discrete-point test. The CET items such as cloze, compound dictation, error correction and writing are under its influence. In recent years, CET has developed CET-SET and internet-based CET (IB-CET) which is impacted by Communicating Testing approach that emphasizes direct testing.

In line with the changing social needs and reforming College English, as well as the advance of testing theories, CET has undergone four major stages of developments (table 1), according to some significant events.

As is shown in table 1, CET started in 1987 with no speaking test and the emphasis was put on reading. In 1999 CET Spoken English (CET-SET) was initiated, which is optional for those who do well in the written test. As for paper-based test, reading is still the key item. A big reform took place in 2005, 100 score system was changed to a norm-referenced system with score ranging from 220 to 710 . In addition, the passing or failing cut-off score was eliminated and a detailed score report would be sent to students instead of certificates. The percentage of Listening part was increased from $20 \%$ to $35 \%$. Initial implementation of IB-CET took place in 2008, whose content mainly consists of three parts: Listening Comprehension, Listening-based Integrated Tasks, and Reading Comprehension. Up to now it coexists with the paper-based test which still remains the mainstream testing method.

\footnotetext{
${ }^{1}$ Norm, a set standard of development or achievement usually derived from the average or median achievement of a large group ("merriam-webster,", 2014).
} 


\begin{tabular}{|c|c|c|}
\hline time frame & big events & content (paper-based) \\
\hline 1987 & CET4 inception in 1987 & listening (20\%) \\
\hline \multirow[t]{4}{*}{$\downarrow$} & CET6 inception in 1989 & reading $(40 \%)$ \\
\hline & certificate for qualifier & vocabulary \& structure(15\%) \\
\hline & & cloze $(10 \%)$ \\
\hline & & writing (15\%) \\
\hline 1999 & CET-SET inception in 1999 & listening (20\%) \\
\hline \multirow[t]{4}{*}{$\downarrow$} & & reading $(40 \%)$ \\
\hline & & vocabulary s structure (15\%) \\
\hline & & comprehesive (10\%)(1) \\
\hline & & writing (15\%) \\
\hline 2005 & score range: $220-710$ & listening $(35 \%)$ \\
\hline \multirow[t]{3}{*}{$\downarrow$} & score report & reading $(35 \%)$ \\
\hline & no cut-off score & comprehensive (15\%) \\
\hline & no certificate & writing $(15 \%)$ \\
\hline 2008 & IB-CET4 inception in 2008 & writing (15\%) \\
\hline \multirow[t]{2}{*}{$\downarrow$} & IB-CET6 inception in 2009 & listening ( $35 \%)$ \\
\hline & & reading $(35 \%)$ \\
\hline 2013 & & translation (15\%) \\
\hline
\end{tabular}

table 1: development phases of CET

(1) comprehensive includes: cloze/error correction or translation/SAQ

\section{DISCUSSION}

\section{A. Contributions of CET}

\section{CET is said to have promoted College English Education}

During the three decades from founding of People's Republic of China to late 1970s, owing to ideological confrontation and domestic turbulence, the English education in China remains a state of intermittence and low level. There was no clear teaching aim and corresponding teaching content, not to mention teaching assessment. According to a research (Yang, 2003), only one third of college graduates could reach the level of reading English with a speed of 17 words per minute. Although College English was a required course, it was in a subordinative position and regarded unimportant comparing to other specialized courses. Many universities and colleges didn't have full-time College English teachers. The main duty of many College English teachers was to teach English majors or other specialized courses. College English teachers usually didn't have their own teaching and research section, and their office was generally called 'MaTiWai', meaning a comprehensive office for courses of Marxism-Leninism \& Mao Zedong Thought, Physical Education and Foreign Language Education.

CET is believed to have produced some beneficial backwash on College English education. Its passing rate as an important official assessing index has pushed institutions to improve their education facilities and enhance quality of College English teachers. Independent department for College English was established in almost every higher education institutions and full-time teachers were employed. Each university and college quickly built its language labs for College English, which called an end to teach listening with a tape recorder.

With the flourishing of College English, the textbooks also witnessed a big development. Many new textbooks for College English have been published. Among these, the most influential ones are the New Horizon College English by Beijing Foreign Language Teaching and Research Press, New College English by Shanghai Foreign Language Education Press, and Experiencing English by Higher Education Press.

Regarding CET certificate as one stepping stone to hunt for a promising job, students have impetus to learn English. These factors definitely have made some contributions to College English education. According to Yang's statistics in table 2 (Yang, 2004), within the 15 years after CET's inception, college students' English proficiency has improved quite a lot, comparing with late 1980s. Many factors have made contributions though, the achievement owns a lot to the CET that can be taken as the First Cause.

\begin{tabular}{|l|l|l|l|l|l|l|l|l|l|}
\hline & \multicolumn{3}{|l|}{ listening } & \multicolumn{2}{l|}{ (20 points) } & \multicolumn{2}{l|}{ reading (40 points) } \\
\hline & $\begin{array}{l}\text { first 5 } \\
\text { years }\end{array}$ & $\begin{array}{l}\text { mid 5 } \\
\text { years }\end{array}$ & $\begin{array}{l}\text { last 5 } \\
\text { years }\end{array}$ & $\begin{array}{l}\text { first 5 } \\
\text { years }\end{array}$ & $\begin{array}{l}\text { mid 5 } \\
\text { years }\end{array}$ & $\begin{array}{l}\text { last 5 } \\
\text { years }\end{array}$ & $\begin{array}{l}\text { first 5 } \\
\text { years }\end{array}$ & $\begin{array}{l}\text { mid 5 } \\
\text { years }\end{array}$ & $\begin{array}{l}\text { last 5 } \\
\text { years }\end{array}$ \\
\hline $\begin{array}{l}\text { students from ordinary } \\
\text { universities }\end{array}$ & 10 & 11.75 & 12.5 & 25 & 26 & 27.5 & 4.5 & 6 & 7.5 \\
\hline $\begin{array}{l}\text { students from key } \\
\text { universities }\end{array}$ & 11 & 13 & 14 & 27 & 28 & 31 & 5.5 & 7.5 & 8.5 \\
\hline
\end{tabular}

table 2: CET item score from 1987 to 2003 (average raw score)

Meanwhile it is a fact that students' spoken English is poor even if they have completed CET. One reason for this might be speaking is not required in CET, and only a small number of students have access to CET-SET. Both teachers and students don't have enough motivation to spend efforts on it. Another reason might be that students don't have an environment to use the language except for a little use in English class. A typical contrast will be Ningbo Nottingham 
University. The Chinese students there could talk freely and attend courses delivered in English only after one year language training (Su \& Chen, 2010). The working language of Nottingham is English and students have to use English to survive there. It shows language environment plays an important role in language acquisition, especially speaking ability.

\section{The practice of CET has accumulated knowledge for test development}

Test development is the entire process of creating and using a test, beginning with its initial conceptualization and design, and culminating in one or more archived tests and the results of their use (Bachman \& Palmer, 1999). It is a complex process involving construct design, items writing, try-out, validation, test giving and feedback. It is especially complicated for large-scale high-stakes standardized test. As far as CET is concerned, it is a nation-wide standardized test with a test population of over 18 million each year (Jin, 2011), and it is a high-stakes test as well since its result is critical for graduates in job market. It is highly demanding to manage such a test. Among the numerous factors in its development process, validity and administration are of great importance which requires special attention.

CET designers have always been seeking to validate the test. Meanwhile standardization requires high reliability. It is important to keep a balance between reliability and validity. From 1993 to 1996, National College English Testing Committee (NCETC) collaborated with British Council (University of Reading exactly), conducted a comprehensive research on CET validity in terms of construct validity, content validity, concurrent validity, predicative validity and face validity. Some weak parts of CET design was identified though, the research result confirmed that CET is a test with high reliability and validity. According to the research (Yang \& Weir, 1998), its internal reliability reaches 0.9 or above and 92\% College English teachers responded that CET is a real reflection of students' English proficiency.

In a broader sense, test administration includes all the managing actions in the process of carrying out the test securely and fairly. For large-scale test like CET, administration is even more important and difficult for unreliable results may occur if the test is not well administered (Weir, 2010). With 2138 higher education institutions (MOE, 2012) and 18 million test takers each year, not to mention a huge number of invigilators and supporting personnel, a slight negligence may result in items leaking, which will cause untold consequences. From items writing, to paper printing, to paper transporting, to test giving, it requires a careful and efficient plan to prevent tragedy from happening. Under the guidance of NEEA Safety and Confidentiality Regulations (MOE, PDCC, MPS, \& SSB, 2004), CET administrators have developed series of rules and practices to ensure test paper's safety. The key ones may be listed as follow:

- Non-disclosure agreement is signed with the personnel who have the chance to access the test items.

-Test papers' transportation from the printing factory to each province, then to each test site is under protection of strict rules.

- Handbook is issued and staff is trained at each site.

-Strict regulations are practiced when the test is given.

Another key factor to ensure the fair-play of test is that each site's environment must be of the same standard, such as classroom facilities (seats, tables, lighting, etc.), noise control, time allotment and listening broadcasting. After 26 years' practicing, almost every test site has been very experienced in ensuring the test environment meets the requirements. Generally the city radio station is asked to give help to broadcast the listening part and students will listen with their own radio receivers. Besides, students are required to bring with them the admission ticket, ID card and student card to prevent cheating and items leaking.

With its knowledge accumulation in validity and administration, CET has promoted itself being more scientific, as well as developed the potential to lend experience to other similar tests.

\section{B. Drawbacks of CET}

\section{It has given rise to test-oriented education}

The good test is an obedient servant since it follows and apes the teaching (Davies, 1968). It is language test that should serve language teaching, and it is irreversible. Teaching enjoys the primary importance. The purpose of CET is to discover how well students have achieved the study objectives of College English and diagnose the strength and weakness of students, so that teaching can be improved. We need to be cautious if a test's side effect overgrows to the extent that it becomes a hurdle to language teaching and learning.

The Ministry of Education regularly evaluates the teaching quality of higher education institutions. The institutions with good evaluation result are approved as qualified in education and will get more share of financial support from government. The worst have to face the fate of losing the qualification to run education in the discipline (MOE, 2011). It is a very important event for institutions. Teaching effect is a key part of evaluation and CET passing rate is usually regarded as one important index of teaching effect (Yu, 2008). To make this index stronger, majority of institutions will push College English teachers to try their best to increase CET passing rate. In some institutions, CET passing rate is connected to the teachers' income. It is not surprising that test-oriented teaching method has been adopted. Numerous other evaluations make the situation even worse.

On the other hand, in the job market, employers usually regard CET certificate (now score report) as one important element of a qualified college graduate and are reluctant to accept applicants without the certificates (Hu, 2005). A higher CET score means a higher guarantee for a better job. College students are incentivized to spend time and effort on CET preparation. They recite the so-called CET key vocabulary, do a lot of test papers, and even pay a lot to attend CET training. The real purpose of learning a foreign language is ignored. The worst part is that some students run the 
risk of cheating for a better score. It is ridiculous that cheating has become a big business in China.

According to Liu and Dai's survey (2004), only 7.1\% of teachers agree that scores of nationwide tests can represent the takers' proficiency level while $13.9 \%$ believe it absolutely does not. $78.2 \%$ would say it doesn't necessarily represent one's language proficiency. According to another survey, 28.4 of students think CET4 is absolutely meaningless, $19.6 \%$ believe it is not important, and only $24 \%$ think that it is important (Liu \& Dai, 2004). The absurdity here is that both educators and students know test-oriented tendency resulted by CET is wrong though, they still stick to it. CET is too powerful to be a scientific test, which calls for immediate change.

\section{It has become a hurdle to College English reform}

According to College English Curriculum Requirements (Higher Education Department, 2007), the teaching aim of College English is to develop students' all-round ability to use English, especially listening and speaking, so that graduates can communicate effectively in English in their future study, work and social intercourse. This coincides with the theory of communicative competence. Under the influence of the theory, it has become widely accepted that communicative language teaching is an effective approach of language education. Both education authorities and teachers know it is good and institutions are encouraged to reform their language teaching methods to focus on communicative competence. However it is hard to evaluate the result of communicative language teaching, since it is very subjective. More importantly, this approach will do harm to the CET passing rate. It is difficult to convince the education authority that students' communicative competence is rising because there is no unified national criterion. However the authority is easy to discover the fall of CET passing rate. Generally the higher institutions are reluctant to take the risk to reform.

Out of utilitarianism, students are more interested in CET training comparing to the teaching model to improve their communicative competence. According to my observation in the university I'm working at and my interview with other teachers, students will ask their teachers to stop their normal teaching plan and focus on CET training when CET is drawing near. Generally the teachers understand students' concern and will compromise. If the teachers don't, many students will recite CET vocabulary or do model tests in class instead of being involved in the class activities. Furthermore, students have the right to evaluate their teacher at the end of each semester. Worrying to be scored low, teachers will cater to students' request. Anyway in the short term, it benefits students, teachers and their institution. However the teaching reform is hindered in the long run.

\section{Its validity and fairness are under debate}

The CET in December 2013 has witnessed some improvement of its validity. The multiple-choice items which are thought as higher reliability but lower validity are largely reduced and some subjective items with higher validity are replenished (table 3). For example, the item of 'cloze' is abandoned which is a typical item of multiple choice. Two passage readings are transformed into the types of banked cloze and information matching, which have higher validity. However, much more efforts are needed to further improve its validity. The purpose of CET is to assess students' all-round ability to use English. One big defect of the test construct is its lack of spoken English, which is assessed in another separate test. Although there are 18 million CET takers each year, only a small part of test takers whose scores are high enough to have the qualification to register for CET-SET, and the worse part is that most of the qualified will give up the opportunity. One reason might be a high score of written test is good enough to compete in job market, so it makes no sense to participate in CET-SET. Another reason might be its inconvenience to attend CET-SET. There are only 30 test sites in the whole country, which means every province has only one test site. Test takers have to travel a lot and undertake the cost for travelling and test fee. As a result, only far less than $1 \%$ of CET takers apply for CET-SET (Cai, 2006). For $99 \%$ of CET takers, their spoken English is not tested. This conflicts with CET's purpose of assessing integrated English ability. In this sense, CET does not fully measure it purports to measure, which puts its validity under doubt.

\begin{tabular}{|c|c|c|c|c|}
\hline const ruct & cont ent & itens & $\mathbf{x}$ & tine \\
\hline writing & writing & essay writing & $15 \%$ & $30^{\prime}$ \\
\hline \multirow{4}{*}{ listening } & short conversations & multiple choice & $8 \%$ & \multirow{4}{*}{$30^{\prime}$} \\
\hline & long conversatons & multiple choice & $7 \%$ & \\
\hline & passages & multiple choice & $10 \%$ & \\
\hline & passage & words/phrases dictation & $10 \%$ & \\
\hline \multirow{3}{*}{ reading } & passage reading & banked cloze & $5 \%$ & \multirow{3}{*}{$40^{\prime}$} \\
\hline & passage reading & informations matching & $10 \%$ & \\
\hline & passage reading & multiple choice & $20 \%$ & \\
\hline translation & paragraph translation & Chinese to English & $15 \%$ & $30^{\prime}$ \\
\hline \multicolumn{3}{|c|}{ total } & $100 \%$ & $130^{\prime}$ \\
\hline
\end{tabular}

Furthermore, as College English Curriculum Requirements (Higher Education Department, 2007) states, 'As China is a large country with conditions that vary from region to region and from college to college, the teaching of College English should follow the principle of providing different guidance for different groups of students and instructing them 
in accordance with their aptitude so as to meet the specific needs of individualized teaching' (p25). However CET as an official assessment of College English teaching effects fails to consider the diversity of regions, institutions and students. All students are tested by one paper, which doesn't correspond with individualized teaching.

Up to 2012, there are 2138 higher education institutions in China (MOE, 2012), mainly including key institutions, ordinary institutions, and institution for adults. The students they recruit differ a lot in terms of English level. The key universities can achieve a higher CET passing rate without much effort. However for the ordinary institutions even if their teachers work much harder, it is difficult to catch up with the passing rate of key universities. Therefore it is not fair to assess different institutions with the same criterion, namely CET.

As far as students are concerned, it is even more unfair. The students from countryside have an obvious disadvantage over urban ones. Only 17\% (Zhang, 2010) of them have the chance to practice their listening in a language lab in their high schools. Mostly their listening is trained in classroom with a recorder. Their listening ability is poor not because they are not motivated enough but owing to the poor facility. In order to pass CET, they have to spend much more time than urban students. Actually many students even the urban ones have to work hard to pass CET at the expense of sacrificing the time for the subjects they like. Students have to reduce their time for other courses just because other courses don't have a national test. It hinders students from learning their disciplinary courses and is not fair for other courses either.

The situation has called for a testing reform, both in constructing new test and in improving the managing system ( $\mathrm{Hu}, 2005)$.

\section{Both Proponents and Opponents Need Reflection}

\section{Proponents' real concern: English education or economic gains?}

The purpose of organizing CET is supposed to evaluate students' English level and offer feedback to College English teaching and learning. Any deviation will do harm to College English teaching. However, social and economic factors strongly influence beliefs about education (Morris, 2009). Are the experts speaking highly of CET out of promoting College English teaching or out of economic gains? This is a sensitive issue. We do wish the proponents really believe CET promotes teaching and learning and this is a purely academic problem. However the test has developed into a big industry: registration fee, reference books, CET training, even cheating and anti-cheating being big business. According to a report on China Youth Daily (Sun, 2006), the national CET committee has collected registration fee of RMB 224 million since 1989, and the fee was not deposited to financial special account. Among the amount, 190 million was disbursed. Blaikie (2010) ever proposed that one stance a researcher can adopt is to be a conscientizer. Conscientization doesn't only mean to be reflective, but more importantly, to have clear conscience about research, especially when the research is relevant to policy making. On one hand rules must be made to specify the collection and disbursement of registration fee. On the other, the experts must clear their conscience, not giving out misleading information just because of some economic gains. Only after the CET is independent of economic purpose, can it be fairly evaluated whether or not it is beneficial to College English teaching.

\section{A question for opponents: will abolition certainly bring out good result?}

Easy is to criticize, difficult is to offer solution. Will goodness of abolishing CET surely outweigh its negative? CET abolition might result in unfavorable results. First, with loss of the national test, English will not be used by the education authorities as an index to evaluate institutions' teaching quality. Naturally the institutions will not consider College English as important as before. College English will lose its significant role in the course system of higher education. Fewer funds will go to College English and the teachers will lose priority in furthering their education and training. Second, without the push of CET, many students may lose their motivation in English learning. Under this situation it can be forecasted that the general English level of college students will decline. This will conflict with the trend of internationalization and globalization. Third, CET is often used as stepping stone to get a decent job. Without CET, students many seek for other English proficiency tests to cater to the employers. There are many tests, such as TOEIC (Test of English for International Communication), PETS (Public English Test System), CATTI (China Accreditation Test for Translators and Interpreters), BEC (Business English Certificate), waiting to fill up the space. These tests are much more expensive and demanding, which will become a new heavier burden for students both economically and mentally.

\section{CONCLUSION}

Extremism is never a scientific and sensible approach. A researcher should situate himself in a neutral but compassionate relationship toward the research subjects (Pillow, 2010). While CET has its own deficiency as discussed above, it might go too far to abolish it. There must be a third way in terms of solution. Moderate wind kindles, much puts out the fire. While balancing CET's positive and negative effects, a substantial reform might be a better way than abolishing or sticking to the status quo. The reform should go beyond the former ones in terms of both test construct and test administration.

First, for the sake of validity, spoken English must be included as one inseparable part of the entire test construct. Speaking test shouldn't be done separately like present, which makes no sense and add no value to CET's validity. The good news is that IB-CET has been developed, which includes 15\% of speaking part. It consists of sentence repeating 
for CET4, oral stating for CET6 and short-answer questions for both. At present there are only 146 institutions who have carried out IB-CET (Fan \& Chen, 2013), which is such a small number comparing with the total higher institutions number of 2138. It is a big progress though. Many efforts are needed to make it mature and widen its scale. Hopefully IB-CET will take place of the paper-based test in the near future.

Second, in terms of test administration, its government-run nature should be changed. The government should withdraw its administrative role from CET and some social organization takes it over. The compelling power of the test will diminish, so it becomes a public test like IELTS or TOEFL. Students should have the right to choose to take part or not. The connection between higher institutions and CET should be cut off and CET passing rate shouldn't be used as an index to assess teaching quality. Only under this condition will the test-oriented education be turned around. Higher institutions will be free to adopt their own teaching models. Hence the College English reform will be deepened.

Last, it is very important that CET's orientation be changed from achievement to proficiency test. Theoretically present CET is an achievement test, however it doesn't test the textbooks' content and the society has seen it as a proficiency test. There is no point to stick to its theoretical orientation of achievement test when it actually is not. The change of orientation will also facilitate test construct which will be free from the restraint of College English Curriculum Requirements. In addition it caters to the need of some graduates who need a proof for their English proficiency.

With over 30 years of efforts in English language education in all levels of schools since China's Reform and Opening-up, the general English level of college students has improved a lot. The present status of College English is still mainly teaching general English, which has been sort of easy and less challenging to many students. It can't arouse students' interest in English learning. With the division of disciplines and labors becoming more intensive, general English can't meet students' demands in their future academic studies and specific job positions. English for Specific Purposes (ESP) might be the orientation of College English reform. As a result it is time for stakeholders to think about testing English for specific purposes.

\section{REFERENCES}

[1] Chman, L. F., \& Palmer, A. S. (1999). Language testing in practice. Shanghai: Shanghai Foreign Language Education Press.

[2] Blaikie, N. (2010). Designing Social Research: the logic of Anticipation. Cambridge: Polity.

[3] Cai, J. (2006). CET Refrom from the Angle of STEP[Cong Riben STEP Kaoshi Gaige Kan CET Kaoshi Gaige]. Foreign Language Teaching Abroad[Guowai Waiyu Jiaoxue](1), 1-7.

[4] Columbia Uni. Validity and Reliability. Retrieved 07/02/2014, from http://ccnmtl.columbia.edu/projects/qmss/measurement/validity_and_reliability.html.

[5] Davies, A. (1968). Language testing symposium; a psycholinguistic approach. London,: Oxford University Press.

[6] Fan, J., \& Chen, H. (2013). A study on IB-CET[Daxue Yingyu Siliuji Wangkao Gaige De Yingyong Yu Yanjiu]. China Educational Technology[Zhongguo Dianhua Jiaoyu](321), 120-124.

[7] Feng, A. (2011). IntroduBachman, L. F. (1999). Fundamental considerations in language testing. Shanghai: Foreign Language Education Press.

[8] Baction: The Apex of ' the Third Wave' - English Language Across Greater China. In A. Feng (Ed.), English language education across greater China. Bristol, UK ; Tonawanda, NY: Bristol, UK ; Tonawanda, NY : Multilingal Matters.

[9] FLTRA. (1985). An Introduction to College English Teaching Syllabus [Guanyu Jieshao Daxue Yingyu Jiaoxue Dagang De Shuoming]. Foreign Language World(3), 23.

[10] Gil, G., \& Adamson, B. (2011). The English Language in Mainland China:A Socialinguistic Profile English language education across greater China. Bristol, UK ; Tonawanda, NY: Bristol, UK ; Tonawanda, NY : Multilingal Matters.

[11] Higher Education Department, M. o. E. (2007). College English Curriculum Requirements. Shanghai: Shanghai Foreign Language Education Press.

[12] Hu, Z. (2005). China's English Education Refrom: Trends and Issues. Foreign Languages in China, 2(1), 4-10.

[13] Hughes, A. (2003). Testing for language teachers / Arthur Hughes. Cambridge ; New York: Cambridge ; New York : Cambridge University Press.

[14] ILR (Producer). types of tests. Retrieved 12/12/2013, from http://www.govtilr.org/TC/scales.html.

[15] Jin, Y. (2011). Fundamental Concerns in High-Stakes Language Testing:The Case of the College English Test. Journal of Pan-Pacific Association of Applied Linguistics, 15(2), 71-83.

[16] Lado, R. (1961). Language testing: the construction and use of foreign language tests; a teacher's book. London: Longmans.

[17] Liu, R., \& Dai, M. (2004). On the Reform of College English Teaching in China. CELEA Journal, 27(4), 3-8.

[18] merriam-webster. Retrieved 10/02/2014, from http://www.merriam-webster.com/.

[19] MOE. (2011). Teaching Assessment Directions[Jiaoyubu Guanyu Gaodeng Xuexiao Benke Jiaoxue Pinggu Gongzuo De Yijian]. Beijing: Retrieved 08/02/2014, from http://www.pgzx.edu.cn/modules/wenjianfabu_d.jsp?id=1107.

[20] MOE. (2012). Namelist of Higher Education Institutions. Retrieved 04/01/2014, from http://www.gov.cn/banshi/2012-08/14/content_12758.htm.

[21] MOE, PDCC, MPS, \& SSB. (2004). NEEA Safety and Confidentiality Regulations [Guojia Jiaoyu Kaoshi Kaowu Anquan Baomi Gongzuo Guiding]. $\quad$ Beijing. $\quad$ Retrieved http://yz.tsinghua.edu.cn/docinfo/board/boarddetail.jsp?columnId=02905\&parentColumnId=029\&itemSeq=2616.

[22] Morris, A. (2009). Evidence Matters:Towards informed professionalism in education. CfBT Education Trust. Retrieved 29/11/2013, from http://www.cfbt.com/en-GB/Research/Research-library/2009/r-evidence-matters-2009.

[23] NCETC. (2006). CET-4 Test Syllabus and Sample Tests (Revised edition). Shanghai: Shanghai Foreign Language Education Press. 
[24] Pillow, W. S. (2010). 'Dangerous reflexivity' Rigour, responsibility and reflexivity in qualitative research. In P. Thomson \& M. Walker (Eds.), The Routledge Doctoral Student's Companion: Getting to Grips with Research in Education and Social Sciences (1st ed., pp. 270). Oxon: Routledge.

[25] Sun, F. (2006, 08/09). Government should forbid paid test [Jianyi Zhengfu Bumen Yu Yiqie Shoufei Kaoshi Tuogou], China $\begin{array}{llllll}\text { Youth Daily [Zhongguo Qingnian Bao]. Retrieved from } & \end{array}$ http://zqb.cyol.com/content/2006-09/28/content_1525476.htm.

[26] Su, Dingfang, \& Chen, Suyan. (2010). Way to success in TEFL in China:a study of the UNNC academic English model. Shanghai: Shanghai Foreign Language Education Press.

[27] Wang, J. (2011). An Introduction to Language Testing [Yuyan Ceshi Gailun]. Beijing: Beijing Language and Culture university Press.

[28] Weir, C. J. (2010). Language Testing and Validation: An Evidence-Based Approach. Beijing: Foreign Language Teaching and Research Press.

[29] Yang, H. (2003). Daxue Yingyu Siliuji Kaoshi Shiwunian Huigu [The 15 years of the CET and Its Impact on Teaching]. Waiguoyu [Journal of Foreign Languages](3), 21-29.

[30] Yang, H. (2004). Cong Siliuji Kaoshi Kan Woguo Daxuesheng Yingyu Yuyan Nengli Xianzhuang[An Analysis of the English Proficiency of the Chinese Students as Reflected in the National CET Test]. Zhongguo Waiyu[Foreign Languages in China], $1(1), 56-60$.

[31] Yang, H., \& Weir, C. (1998). Validation Study of the National College English Test. Shanghai: Shanghai Foreign Language Education Press.

[32] Yu, Z. (2008). The problmes and refrom of CET [Daxue Yingyu Siliuji Kaoshi Cunzai De Wenti Ji Gaige Lujing]. Modern Education Science [Xiandai Jiaoyu Kexue](1), 93-96.

[33] Zhang, S. (2010). An Investigation of English Listening Comprehension of Students from Rural Areas[Nongcun Daxuesheng Yingyu Tingli Zhuangkuang De Diaocha Yanjiu]. Theory and Practice of Education[Jaoyu Lilun Yu Shijian](3), 52-54.

Fei Ma was born in Xi' an, China in 1977. He is doing his doctorate in education at the University of Nottingham Ningbo China. $\mathrm{He}$ is currently a lecturer in the College English Department of Zhejiang Wanli University, Ningbo, China. His research interests focus on teaching and reform of English as a Foreign Language in China. 